\title{
Inclusive public space: rethinking practices of mitigation, adaptation and transformation
}

\author{
Karina Landman ${ }^{1}$
}

Published online: 13 August 2020

(c) Springer Nature Limited 2020

Recent decades have brought about an increased focus on public space as part of building more inclusive and sustainable neighbourhoods and cities. Not only are the development of public space highlighted as important in the Sustainable Development Goals and in the New Urban Agenda, but they have also become the focus of movements such as New, Sustainable and Tactical Urbanism. However, recent events such as the outbreak of Covid-19 and protests by Black Lives Matter, have shaken our ideas and perceptions of public space. It forces us to pause for a moment and reconsider the meaning for and threats to inclusive public space.

Broadly, inclusive refers to something containing a specified element of a whole or not excluding any section of society or any party (Oxford Dictionary 1999, p. 717). In this sense, inclusive public space would allow for different parts or groups of society to be accommodated in public space or in other words for social and physical inclusion. For example, making space for young people (Crane 1999), skate-boarders (Carmona 2010) and different race groups (Edgell 1998) in public space or for informal livelihoods (Chen and Kihato 2018) and pop-up markets (Madanipour 2017). However, the notion of inclusive public space has also been challenged by growing security concerns and debates related to whether inclusive or exclusive spaces would be safer. Consequently, certain spaces become monoculturally dominated, undermining the intention for public spaces to be democratic places for all (Shaftoe 2008, p. 16). This has also recently been extended to question the validity of certain actions, such as protests in the name of maintaining security. How can we consider the safety of people

Karina Landman

karina.landman@up.ac.za

https://www.up.ac.za

1 Department of Town and Regional Planning, Faculty of Engineering, Built Environment and Information Technology, University of Pretoria, Room 1-4, Building 8, South Campus, Private Bag X20, Hatfield 0028, South Africa without excluding some? How can we make room for different groups of society in the public space? How can we allow for different groups to voice their concerns within public space without the fear of being arrested? How can we ensure that the nature of public space is culturally inclusive and do not evoke traumatic memories?

These questions need to be considered if we strive towards more inclusive public spaces. This special issue of Urban Design International invited different scholars and practitioners to offer their insights through in-depth case studies and practical interventions. This issue seeks to not only question the notion of inclusive public space in its various manifestations but also to interrogate it within different contexts. Consequently, perspectives from both the global South and North are represented, as well as from the East and West. This does not only highlight vast cultural differences and political challenges but also show some similarities in terms of more common concerns and opportunities.

\section{Reconsidering the nature and use of public space in $\mathbf{2 0 2 0}$}

The recent global events have forced many observers across the world to rethink the nature and use of public space. As the outbreak of Covid-19 spread across the world in the early months of 2020 and gripped many countries, governments responded with various forms of lockdown to contain the spread of the virus. In many places, for example in Italy and Spain, this resulted in eerie and haunted images of some of the world's most well-known public spaces being deserted and empty. San Marco Plaza in Venice lay silent with only the buildings witnessing the empty space. In other parts of the world, where the restrictions were not that severe, people were still allowed out into public space, but with strict measures of social distancing in place. Novel signs reminded visitors of the new rules, enforced by law enforcement agents or in extreme cases, by robots, for example in Singapore. 
Freedom was restricted and measures of mitigation in public space became the new norm to reduce risk and ensure the safety of people against the spreading new virus.

While people were still in shock and trying to come to grips with the new reality after Covid-19 and the often devastating economic impacts, a second major event shook the world. Towards the end of May, George Floyd, a black man, was accosted by a white police agent and pinned down on the street with his knee on his neck for more than 9 min. Meanwhile, Mr Floyd was crying out that he cannot breathe. He died on his way to the hospital. This lead to a huge wave of protests in the United States and others parts of the world of people voicing their discontent over the brutal killing of a black man by a white police officer, opening old wounds and leading to boiling anger of continuous practices of discrimination and existing inequality. All this played out in public space. Overnight streets became battlegrounds of peaceful protests and not so peaceful confrontations between protestors and law enforcement agents. The eyes of the world turned to the places of protests, where the traditional role of the street was temporarily undermined. Voices of thousands adapted once customary streets into channels of vibrant action, while artists changed the landscape through murals across the world, depicting the face of George Floyd and often the words "I cannot breathe". More recently, due to the passing of new security law, the voices of the people and the freedom to protest have become severally challenged in the streets of Hong Kong as practices of "succession, subversion or terrorism" can now lead to imprisonment. A number of protestors have been arrested in the city's public spaces. Practices of public space adaptation, including large numbers of diverse people gathering in public space, forced the world to not only reconsider the nature of inclusive public space but also what can and should take place in such spaces.

As more people started to speak out against the injustices in the world, the movement gained momentum under what has been called Black Lives Matter. Not only injustices of the present, but also of the past and into the future. Protest action expanded to question the representations of oppression in public space. Soon the statues of prominent figures who gained wealth through slave trade or played leading roles during colonialism were targeted. One by one the old icons of the past were toppled or removed-from Columbus in the USA and Colston in the UK to Leopold II in Belgium. In South Africa, the controversial figure of Pres Paul Kruger-fenced in from previous attempts to remove him 4 years ago during calls for decolonisation-was again defaced with spray paint along with four other statues of Boer warriors surrounding him. These acts reopened up the debate related to the meaning of structures in the built environment. It questions the value of being aware of history versus the feelings or memory evoked by these statues. As explained by a historian, Ana Lucia Araujo on CNN, if the trauma of brutal memory linked to the actions committed by these historical figures outweighs the historical facts, then it calls for the transformation of space or in other words, the removal of symbols of oppression (Euronews 2020). The increasing debate around the world related to the removal of historical figures has opened up many questions related to practices of the transformation of public space to be more inclusive.

\section{Is there still hope for inclusive public space? Exploring narratives from five cities}

This special issue seeks to build on these discussions and events and broaden the ways in which we can reconsider inclusive public space. Specifically, we are interested in whether users in public space experience these spaces as inclusive and if not, why not and how this can be changed to be more inclusive. Through this endeavour, we hope to show that inclusive public space does not have to remain an elusive ideal but can become a reality through various types of interventions.

The first narrative is about intercultural interactions and perceptions in public space in England, in the northern city of Bradford. The paper shows how people experience other people from different ethnics groups and or genders in some of the inner city's public spaces. Ganji and Rishbeth illustrate how the nature of physical space can enable more meaningful interactions and thus create opportunities for more inclusive public space. The potential for inclusive public space is therefore influenced by who uses the space, where and when and how this make other users feel.

In the second story, Roa, Fois and Velasco offer detail about a more practical process of regeneration towards more inclusive public space. The article focusses on how to adapt the existing public environment in the City of Guayaquil in Ecuador through urban design interventions and the improvement and reconnection of public space. The authors argue that reconnection should occur through both tangible connections such as green infrastructure, street furniture and cycle paths and intangible connections that create links between the city and its users, for example, imaginary paths, nodes of convergence and collective memories. Thus, to be inclusive, does not only relate to the physical condition of the space but also relates to the meaning and opportunities it creates for the users.

The meaning of space should, however, extend beyond the local inhabitants of a city. Barreiro and Gonzalez share a narrative about Palermo in Sicily which details the challenges presented through an influx of migrants and what this means for the adaptation and transformation of existing spaces in the old historic centre of the city. The article reconsiders how to enable and produce more inclusive public 
space in a multicultural environment where the arrival of the migrants have raised many questions about inter-cultural place-making. The authors show how involving more people from various communities and reclaiming old spaces can create opportunities for the evolution of and the emergence of more inclusive public space.

In Hong Kong, Bruyns and Nel tell a story of limited public space in Hong Kong and how people have adapted the existing public spaces, albeit often in temporary ways, to reclaim and appropriate existing space in more inclusive ways. This occurs within a climate of large scale privatization of space in the city, with restrictive use and privileges. This reclamation of space is referred to as lateral privatization, conjuring up notions of the right to the city and physically taking temporary ownership or reclaiming a specific part of this space. The authors offer two examples of lateral privatization, namely the Umbrella Movement where activists occupied and temporary adapted public spaces through sit-ins, creating study spaces and using spaces to address crowds, as well as the occupation and transformation of spaces by Foreign Domestic Workers every Sunday to gather and communicate. They argue that lateral privatization challenges us to reconsider the notion of inclusive public space through people's actions in micro territories to temporarily redefine the meaning and nature of these spaces.

Returning to the global south, Makakavhule and Landman share the tale of the search for greater democracy in South Africa's changing public spaces. The article explores the challenges and opportunities for deliberative democracy and the creation of more inclusive public space in the capital city of South Africa, the City of Tshwane, as the municipal area is known. The authors show that while there is often resistance or an inability to facilitate spatial democracy in Tshwane, there are also opportunities in this regard by giving people a voice and enabling bottom-up dialogue. At the same time, they indicate that while democratic space may be hampered through the unequal distribution of space or confrontation within public space, efforts towards the development of public space in former marginalized or poorer areas of the city can create opportunities to address these challenges, paving the way for more inclusive public space.

\section{Divergent stories and common threats}

The articles illustrate five divergent stories of attempts to understand the use of public space in multi-cultural societies and different contexts. While some of these stories focus more on the findings of research projects or observation of changes occurring in public space, others are geared more too specific urban design interventions related to the improvement or regeneration of public space. However, there are also a number of common threats present in these accounts.

The first common threat refers to the clear relationship between designed space and the lived experience of the users of these spaces. For example, the study in Bradford illustrates how the design of spaces can make people feel comfortable to only observe from a distance or to engage closer to playgrounds. In Ecuador, the urban designers were cognizant of the intangible connections or urban signs that fill the city with codes that inhabitants interpret for their use and enjoyment. Second, the value of mixed activity spaces was clearly articulated. In Bradford, there was a positive relationship between mixed activity spaces and the potential for inter-cultural activity. Interviews indicated that they enjoyed these more inclusive spaces that seem to be able to accommodate people of different colour, culture and class. Mixed development also featured strongly in South Africa as a means to enable more inclusive and democratic public space. The discussion highlights two challenges for the achievement of deliberative democracy in space, namely homogenisation and exclusion. These challenges can be countered through diversity and mixed development, as was evident in many parks across the City of Tshwane. Third, the facilitation and creation of inclusive public space are hindered by ethnic and gender dis-association. In Palermo, one of the key challenges was to articulate a meaningful inclusion of multiple cultural identities in the shaping of the public space. This was especially challenging in a context filled with multicultural groups that are often socially disconnected. Similarly, users of the public spaces in Bradford were often discouraged to use these spaces due to the presence of male groups or certain ethnic groups. However, interestingly in Hong Kong, foreign domestic workers countered this lack of belonging or association by purposefully reclaiming space for a short period on a Sunday to assert their right to the city and facilitate a form of inclusion in space. Finally, inclusive space is threatened by the unequal distribution or limited amount of public space, often exacerbated by the privatization of public space. It is pointed out that being one of the cities in the world with the highest densities, Hong Kong does not have an adequate amount of public space. In addition, some accessible spaces are in fact privatised and controlled and are thus not inclusive. Lateral privatization, as illustrated by the discussion, offers a way to temporarily take back portions of the space for those who are often excluded from these spaces. Likewise, South Africa has also witnessed the privatization of public space through the creation of pseudo-public spaces in shopping centres or common open spaces in gated communities, creating exclusive space for selected groups. As indicated above, a focus on diversity and mixed development has the potential to enable more democratic and inclusive spaces. 


\section{The way forward and the role of urban design}

Inclusive public space does not have to remain as an idea on paper or in the minds of urban designers. There is enough evidence to show that, despite many challenges, it is possible to achieve it to some extent, either temporarily or in more permanent ways. However, it means that urban designers need to rethink practices of mitigation, adaptation and transformation of public space, both in terms of process and product. In some cases, it may translate in a temporary change of use, either in terms of activities or users. This can mitigate a range of safety concerns. Second, the traditional nature and/or use of public space may need to be adapted through protest actions or urban design interventions to accommodate different activities, either temporarily or on a more permanent basis. Various forms of public space adaptation have the potential to counter practices of exclusion, either physically or symbolically. Finally, in some cases, a complete re-imagination of public space is necessary to enable meaningful and inclusive public space. This may require a number of urban design interventions linked to regeneration or upgrading projects to create new opportunities for a much broader multicultural public and remove signs of oppression or discomfort, both physically and socially.

\section{References}

Carmona, M. 2010. Contemporary public space: Critique and classification; Part one: Critique. Journal of Urban Design 15 (1): 123-148.

Chen, M., J. Harvey, C. Wanjiko Kihato, \& C. Skinner. 2018. Inclusive public spaces for informal livelihoods: A discussion paper for urban planners and policy makers. Prepared by WIEGo for Cities Alliance. https://www.citiesalliance.org/sites/default/files/Publi c\%20Space\%20Discussion\%20Paper_0.pdf.

Crane. 1999. Young people and public space: developing inclusive policy and practice. Presented at the International Conference on Young People and Social Exclusion, University of Strathclyde, Glasgow. https://eprints.qut.edu.au/3/1/Crane_syij_article.pdf. Accessed 10 September 1999

Edgell Becker, P. 1998. "Making inclusive communities" congregations and the "Problem" of race. Social Problems 45 (4): 451-472.

Euronews. 2020, Confronting Colonisation, CNN. https://www.youtu be.com/watch? $\mathrm{v}=\mathrm{oH}$ _cSn4SnE4\&feature=youtu.be).

Madanipour, A. 2017. Cities in time: Temporary urbanism and the future of the city. London: Bloomsbury.

Oxford Concise English Dictionary. 1999. Oxford University Press.

Shaftoe, H. 2008. Convivial urban spaces: Creating effective public places. London: Earthscan.

Publisher's Note Springer Nature remains neutral with regard to jurisdictional claims in published maps and institutional affiliations. 